\title{
Editorial note for the special issue on 'Sap flow and hydraulic functioning' of TREES: structure and function
}

\author{
Achim Bräuning ${ }^{1} \cdot$ Kathy Steppe $^{2}$
}

Published online: 20 January 2016

(C) Springer-Verlag Berlin Heidelberg 2016

How does tree ecophysiological response to environmental forcing translate into wood anatomical structures of the xylem and its hydrological functioning? What can wood structural properties tell us about potential fitness of plant species to environmental stress expected from climate change scenarios? How does the water budget of trees respond to changes in local hydroclimate in different climatic settings or development stages of forest ecosystems? Finally, how do plant structures and functional traits support the survival of saplings of trees growing at the edge of survival conditions? These important questions were intensively discussed at the 9th International Workshop on Sap Flow in Ghent, Belgium during 4-7 June 2013. The response of trees and forests to environmental stressors is also the key topic of the COST-Action FP1106 STReESS, "Studying Tree Responses to extreme Events: a SynthesiS".

In the current volume of trees, five papers using a variety of scientific approaches, and addressing different studied tree ecophysiological and anatomical parameters are combined in a special section, while other papers have already been published in an earlier issue.

Subarctic latitudes are among the most affected areas of global climate change. Patankar et al. (2015) study

Achim Bräuning

achim.braeuning@fau.de

1 Institute of Geography, University Erlangen-Nuremberg, Wetterkreuz 15, 91058 Erlangen, Germany

2 Laboratory of Plant Ecology, Faculty of Bioscience Engineering, Ghent University, Coupure links 653, B-9000 Ghent, Belgium the impact of increasing permafrost active layer thickness on sap flow of black spruce trees growing in peat bogs, and found a $>60 \%$ reduction in sap flow compared to trees growing on still firm permafrost. This drastic reduction in activity is attributed to drying of surface soil layers where rooting occurs due to permafrost melt, and demonstrated a very direct tree physiological response to changing environments. Interestingly, parent trees growing in clonal structures with their saplings created by branch layering support the water budget of their daughter trees to about $5 \%$ under normal conditions, but this contribution may increase up to $25 \%$ of the instantaneous transpiration in some cases (Šenfeldr et al. 2016).

In a tropical montane cloud forest in central Mexico, night-time transpiration in nights following foggy conditions triggered by cold fronts, may amount up to more than $30 \%$ of daytime transpiration in certain tree species. Such relatively high night-time transpiration suggests a nutrient uptake benefit for trees growing in tropical or subtropical environments with typical low soil $\mathrm{pH}$ values and low nutrient availability combined with no water limitation (Alvarado-Barrientos et al. 2015). The impact of soil water availability and tree size on sap flux density of New Zealand Kauri (Agathis australis) revealed that larger trees that have a higher amount of stem water storage were more responsive to vapor pressure deficit, whilst smaller trees that have limited access to deeper soil water reservoirs were more responsive to soil drying (Macinnis-Ng et al. 2016).

Beside climate and soil, plant functional traits are major determinants of water use strategies of plants. Along an elevation gradient in southeast Brazil's Atlantic rain forest, changes in water availability increase the portion of woody species with more conservative water use strategies 
(Rosado et al. 2016), suggesting that water use constraints exist also for tropical rainforest trees in montane cloud forests, questioning the resilience of these ecosystems under possible future drier conditions of changing forest structure.

By conducting a light-exclusion experiment on artificially drought-stressed Populus deltoides $\times$ nigra 'Monviso' trees, Bloemen et al. (2016) demonstrate that $\mathrm{CO}_{2}$ assimilated by bark and woody tissue photosynthesis contributes to maintain the hydraulic function of the xylem. Local sugars may help maintain cell turgor under drought stress or may support repairing xylem embolism (Steppe et al. 2015). Light exclusion under well-watered conditions lead to a stem growth reduction of around $30 \%$, and under drought stress more vessels were still hydraulically functional in plants exposed to light, pointing to the fact that branch and stem photosynthesis may strongly impact the resilience of hydraulic functioning under drought stress (Vandegehuchte et al. 2015). In another experiment, Urban et al. (2014) inoculated young elm trees (Ulmus glabra) with spores of Dutch elm disease (Ophiostoma novo-ulmi) and found that sap flow came to a complete stand-still after only 16 days, before any visual symptoms were detectable on the trees. Hence, sap flow measurements may be useful to provide quantitative information about progression of pathogens in the stem, and related changes in hydraulic conductivity in different tree species.

The explanatory power and mechanistic understanding of empirical ecophysiological measurements can be greatly enhanced by modeling. By implementing different rates of crop load in a water and carbon transport model, De Swaef et al. (2014) relate differences in crop load to differences in xylem and phloem water potential components leading to different rates of diel stem diameter variations and growth rates. Van de Wal et al. (2015) carried out a detailed analysis of the spatial variations of sap flux density under different weather conditions in the widespread mangrove species Avicenna marina, a species with complex xylem structure including successive cambia and internal phloem (Robert et al. 2011). Ignoring the spatial variability in sap flux density in radial and azimuthal direction led to over- or underestimations of sap flux of $25 \%$ and up to $102 \%$, respectively. Furthermore, the shape of radial profiles of sap flow rates varied substantially under changing meteorological conditions, pointing to the risk of large errors when short-term measurements in individual parts of such trees are simply upscaled to projections of long-term water use of whole plants. For A. marina and Rhizophora mucronata in a mangrove forest in Mombasa, Kenya, De Deurwaerder et al. (2016) showed that morphological and anatomical responses induced by high siltation were very similar to drought stress-induced responses. Mangrove trees growing in high-siltation sites had more but smaller leaves with a smaller stomatal area compared to the ones growing in low-siltation sites. In addition, A. marina showed an increase in phloem band/growth layer ratio, whereas $R$. mucronata increased vessel density. These anatomical adaptations together with an unchanged branch hydraulic conductivity point to a survival mechanism to cope with this less favorable environment.

The variety of examples compiled in this SI highlight the scientific relevance, applicability, and methodological caveats of sap flux measurements under natural and experimental conditions. We hope that it stimulates more researchers to apply this powerful and technically feasible method to learn more how trees respond to changing climatic conditions, and increasing environmental stress.

Author contribution statement $\mathrm{AB}$ and $\mathrm{KS}$ contributed equally to wrote the paper and co-edited the special issue on sap flow andhydraulic functioning of trees.

Acknowledgments The guest editors wish to acknowledge the support of COST-Action FP1106 STReESS, and its Chair, Dr. Ute Sass-Klaassen, for organizing this event.

\section{References}

Alvarado-Barrientos MS, Holwerda F, Geissert DR, Muñoz-Villers LE, Gotsch SG, Asbjornsen H, Dawson TE (2015) Nighttime transpiration in a seasonally dry tropical montane cloud forest environment. Trees 29:259-274. doi:10.1007/s00468-014-1111-1

Bloemen J, Vergeynst LL, Overlaet-Michiels L, Steppe K (2016) How important is woody tissue photosynthesis in poplar during drought stress? Trees. doi:10.1007/s00468-014-1132-9

De Deurwaerder H, Okello JA, Koedam N, Schmitz N, Steppe, K (2016) How are anatomical and hydraulic features of the mangroves Avicennia marina and Rhizophora mucronata influenced by siltation? Trees. doi:10.1007/s00468-016-1357-x

De Swaef T, Mellisho CD, Baert A, De Schepper V, Torrecillas A, Conejero W, Steppe K (2014) Model-assisted evaluation of crop load effects on stem diameter variations and fruit growth in peach. Trees 28:1607-1622. doi:10.1007/s00468-014-1069-Z

Macinnis-Ng C, Wyse S, Veale A, Schwendenmann L, Clearwater M (2016) Sap flow of the southern conifer, Agathis australis during wet and dry summers. Trees. doi:10.1007/s00468-015-1164-9

Patankar R, Quinton WL, Hayashic M, Baltzer JL (2015) Sap flow responses to seasonal thaw and permafrost degradation in a subarctic boreal peatland. Trees 29:129-142

Robert EMR, Schmitz N, Boeren I, Driessens T, Herremans K, De Mey J, Van de Casteele E, Beeckman H, Koedam N (2011) Successive cambia: a developmental oddity or an adaptive structure? PLoS One 6:e16558

Rosado BHP, Joly CA, Burgess SSO, Oliveira RS, Aidar MPM (2016) Changes in plant functional traits and water use in Atlantic rainforest: evidence of restrictions to water loss in spatio-temporal scales. Trees. doi:10.1007/s00468-015-1165-8

Šenfeldr M, Urban J, Maděra P, Kučera J (2016) Redistribution of water via layering branches between connected parent and daughter trees in Norway spruce clonal groups. Trees. doi:10. 1007/s00468-015-1157-8

Steppe K, Sterck F, Deslauriers A (2015) Diel growth dynamics in tree stems: linking anatomy and ecophysiology. Trends Plant Sci 20:335-343. doi:10.1016/j.tplants.2015.03.015 
Urban J, Dvořák M (2014) Sap flow based quantitative indication of progression of Dutch elm disease after inoculation with Ophiostoma novo-ulmi. Trees 28:1599-1605

Van de Wal BAE, Guyot A, Lovelock CE, Lockington DA, Steppe K (2015) Influence of temporospatial variation in sap flux density on estimates of whole-tree water use in Avicennia marina. Trees 29:215-222. doi:10.1007/s00468-014-1105-z
Vandegehuchte MW, Bloemen J, Vergeynst LL, Steppe K (2015) Woody tissue photosynthesis in trees: salve on the wounds of drought? New Phytol 208:998-1002 